\title{
New records of an alien fungus Erysiphe corylacearum (Erysiphales, Ascomycota) in Ukraine
}

\author{
Vasyl P. Heluta ${ }^{1}$ \\ M.G. Kholodny Institute of Botany, National Academy of Sciences \\ of Ukraine, 2 Tereshchenkivska Str., Kyiv, 01004, Ukraine
}

Stella I. Fokshei

Hutsulshchyna National Nature Park, 84 Druzhby Str., Kosiv 78600, Ivano-Frankivsk Region, Ukraine

\begin{abstract}
This article provides information on new records of an alien powdery mildew fungus Erysiphe corylacearum (Erysiphales, Ascomycota), previously recorded in Ukraine only in Crimea and at two localities in Kyiv. In the end of September 2019, this species was additionally found in six sites of Hutsulshchyna National Nature Park (Ivano-Frankivsk Region, the Ukrainian Carpathians). This fungus has a primary East Asian-North American geographical range, but in recent years has started to occur in Turkey (2013), Azerbaijan (2016), Ukraine (2016), Iran (2017), southwestern Russia (2017), Georgia (2018), and Switzerland (2019). Therefore, it is concluded that this species migrated to Ukraine from the eastward. In the most of new localities, E. corylacearum significantly damaged common hazel (Corylus avellana) and abundantly produced fruiting bodies with asci and spores. Considering that this species is already recorded in the Ukrainian Carpathians and Switzerland and due to the ability of powdery mildew fungi to spread rapidly over new territories, it is expected that E. corylacearum will soon appear in various countries of Western Europe.
\end{abstract}

Key Words: adventive species, Corylus, common hazel, invasion, powdery mildews, Ukrainian Carpathians

\section{INTRODUCTION}

As previously reported [Heluta, 2006], over the last decades the species composition of powdery mildews in Ukraine has increased significantly due to the penetration of alien species primarily distributed in North America and East Asia. During almost two decades of the 21st century, seven species from North America have been recorded here, namely Erysiphe azaleae (U. Braun) U. Braun \& S. Takam. [Heluta et al., 2004], E. flexuosa (Peck) U. Braun \& S. Takam. [Heluta, Voytyuk, 2004], E. elevata (Burrill) U. Braun \& S. Takam. [Heluta et

Accepted for publication: 15 April 2020

1E-mail:vheluta@botany.kiev.ua al., 2009a], Golovinomyces greeneanus (U. Braun) V.P. Heluta [Heluta, Korytnyanska, 2011], E. platani (Howe) U. Braun \& S. Takam. [Heluta et al., 2013], Podosphaera amelanchieris Maurizio [Heluta, Hirylovich, 2016], and E. symphoricarpi (Howe) U. Braun \& S. Takam. [Heluta et al., 2016b]. The same number of species came from Asia. They are E. syringae-japonicae (U. Braun) U. Braun \& S. Takam. [Seko et al., 2008, 2011], E. kenjiana (Homma) U. Braun \& S. Takam. [Heluta et al. 2009b], Neoerysiphe geranii (Y. Nomura) U. Braun [Heluta et al. 2010], E. magnifica (U. Braun) U. Braun \& S. Takam. [Palagecha, Chumak, 2011], E. macleayae R.Y. Zheng and G.K. Chen [Heluta, Kravchuk, 2015; Heluta et al., 2016a], E. salmonii (Syd. \& P. Syd.) U. Braun \& S. Takam. [Heluta et al., 2017], and E. corylacearum U. Braun \& S. Takam. [Bulgakov, 2018; Heluta et al., 2019]. The latest reported species, E. corylacearum, the hazel parasite, was found in 2016 in Crimea [Bulgakov, 2018] and in September 2017 at two localities of Kyiv [Heluta et al., 2019]. The search for this species in the following year at other parts of Kyiv and the outskirts of the city was unsuccessful.

In September 2019, the authors made an expedition to Hutsulshchyna National Nature Park, the Ukrainian Carpathians. During the survey of natural and seminatural plant communities, plants of Corylus avellana $\mathrm{L}$. affected by powdery mildew were found at six localities (Fig. 1). Microscopic examination showed that in all cases, the disease was caused by E. corylacearum. In this brief communication, we report these new findings of the fungus, adventive in Europe.

\section{MATERIAL AND METHODS}

The affected leaves of Corylus avellana were collected in September 2019 in the Kosiv District of IvanoFrankivsk Region, only on the territory of Hutsulshchyna National Nature Park. They were herbarized in the usual way. Samples of Erysiphe corylacearum previously collected in Kyiv on C. avellana and in the Far East of the Russian Federation on $C$. heterophylla Fisch ex Bess., a typical host plant of this species, were also examined for comparison. Morphological structures for light microscopy were prepared by standard methods in distilled water, then studied and photographed under a light microscope "Primo Star" (Carl Zeiss, Germany) 


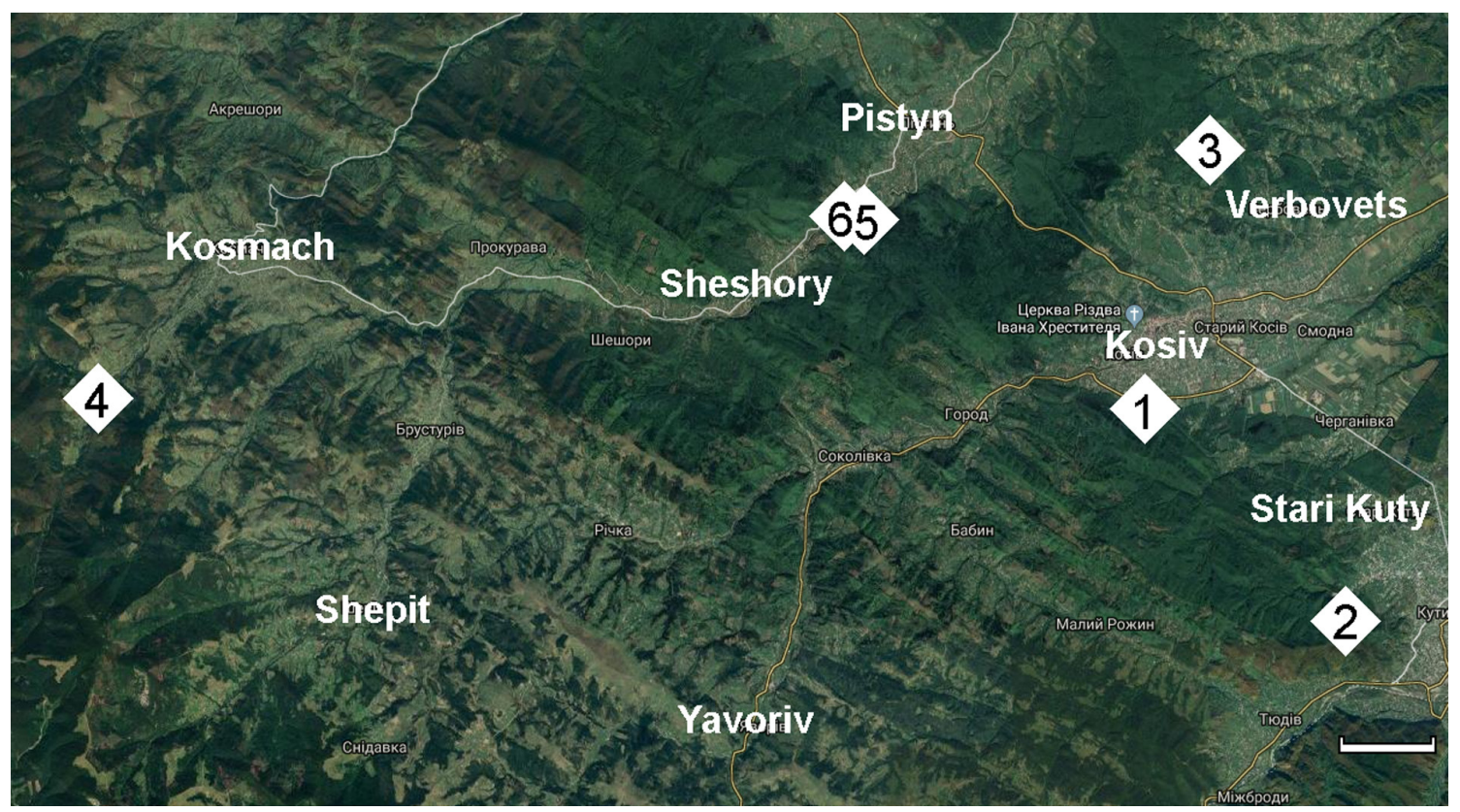

Figure 1. Localities of Erysiphe corylacearum in Hutsulshchyna National Nature Park recorded in September 2019 indicated by rhombs (the numbers in rhombs correspond to the locality numbers given in the text; bar $=2 \mathrm{~km}$ ); Google map was used as a basis.

with the camera "Canon A 300" and the software "AxioVision 4.7". The specimens were deposited at the Herbarium of Fungi and Fungi-like Organisms of KW (abbreviation according to Index Herbariorum, http:// sweetgum.nybg.org/science/ih/).

\section{RESULTS AND DISCUSSION}

Microscopic examination showed that all studied Carpathian specimens belong to Erysiphe corylacearum and are morphologically very close to those previously collected in Kyiv. However, like the Kyiv materials [Heluta et al., 2019], they are slightly different from the Far Eastern samples. The fungus from the Carpathians also has somewhat larger fruit bodies; consequently, the ratio between the length of the appendage and the diameter of the chasmothecium varies, and therefore, the appendages seem shorter (Fig. 2b-d). In addition, number of asci in the fruit body is larger (3-7 instead of 2-4) and asci are slightly elongated and almost all of them had a short stalk.

In Ukraine, E. corylacearum was collected only on leaves of Corylus avellana. Below is a list of six new records of this species.

Erysiphe corylacearum U. Braun \& S. Takam., in Braun, Schlechtendalia 8: 33. 2002.

1. The southern outskirts of Kosiv, 82 Druzhby Str., near office of Hutsulshchyna National Nature Park, on forest edge, 23.09.2019, V.P. Heluta, S.I. Fokshei (KW$\mathrm{M}$ 71282). The development of the fungus was minor.

2. Stari Kuty village surroundings, Ovyd Mountain slope, deciduous forest, 25.09.2019, V.P. Heluta, S.I. Fokshei (KW-M 71283, 71284). One locality, the lesion was intense.

3. Verbovets village surroundings, Mezhydorohy tract, hazel planting along ground path, 26.09.2019, V.P. Heluta, S.I. Fokshei (KW-M 71285). The development of the fungus was intense.

4. Kosmach village surroundings, semi-natural plant community, 27.09.2019, registered by V.P. Heluta through the window of the expedition car. The lesion was very intense, clearly visible.

5. Sheshory village, right bank of the Pistynka River, near the suspension bridge over the river, semi-natural phytocenose, 27.09.2019, V.P. Heluta (KW-M 71286). The lesion was intense.

6. Sheshory village, near estate of Sheshory Nature Conservation Research Branch of Hutsulshchyna National Nature Park, semi-natural plant community, 29.09.2019, V.P. Heluta (KW-M 71287). The lesion was minor, inconspicuous.

Thus, E. corylacearum has spread beyond the city of Kyiv and begins to quickly occupy other distant areas. In most Carpathian localities, its development was quite intense. It should be noted that in all cases, even with 

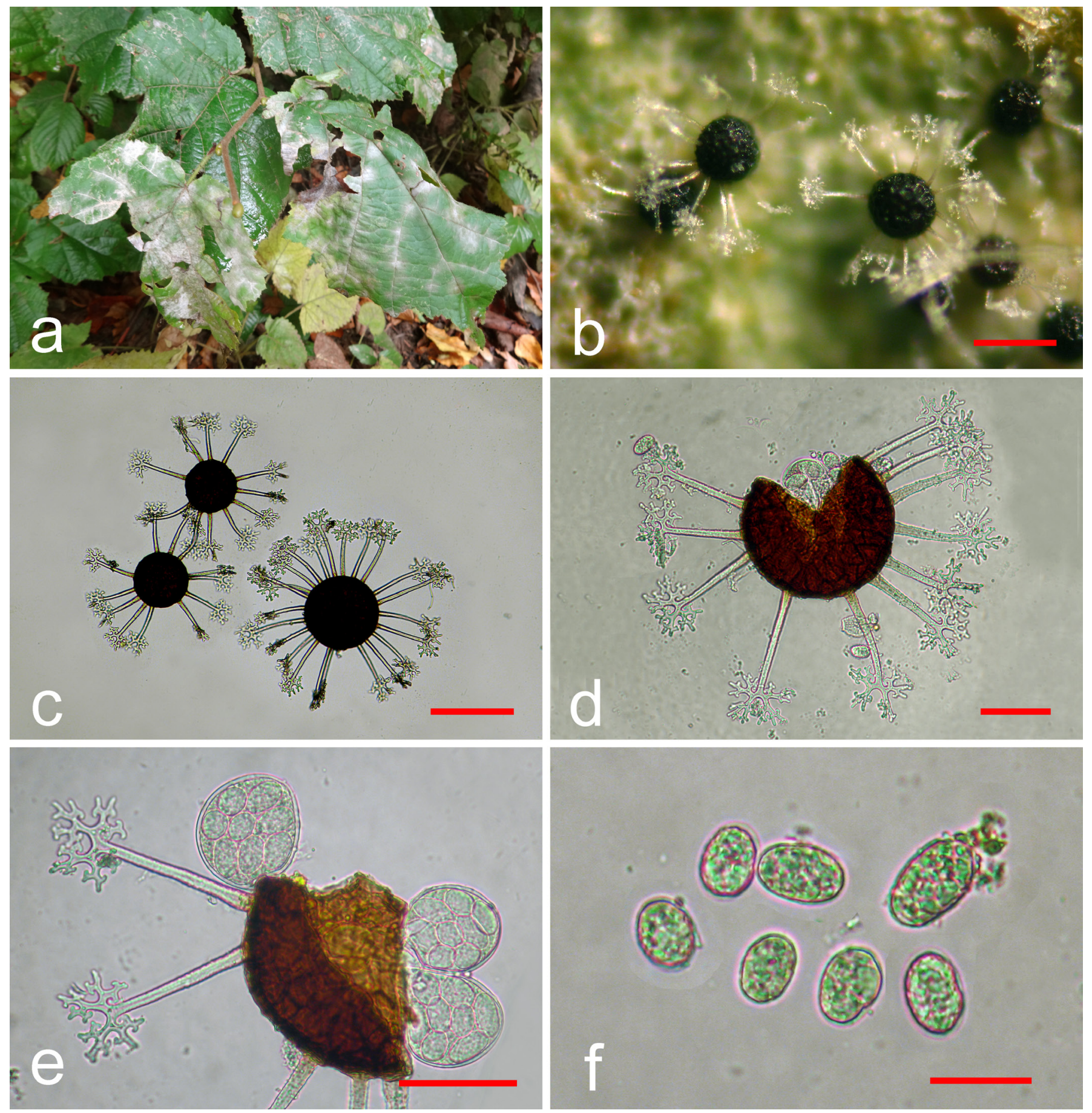

Figure 2. Erysiphe corylacearum on Corylus avellana (KW-M 71285): a. infected leaves; b. chasmothecia on the underside of the leaf; c. chasmothecia; d. squashed chasmothecium; e. ruptured chasmothecium with appendages and 8-spored asci; f. ascospores. Bars: $\mathrm{b}, \mathrm{c}=100 \mu \mathrm{m} ; \mathrm{d}, \mathrm{e}=50 \mu \mathrm{m} ; \mathrm{f}=20 \mu \mathrm{m}$. 
slight damage to the host plant, the fruiting bodies of the fungus were abundantly formed on the colonies (Fig. 2a-c). As a result of microscopic examination, it was found that they contain mature asci with spores (Fig. 2d-f). Therefore, the Carpathian Mountains have favorable conditions for the spread of this fungus.

In the introduction part, we provided a list of alien Asian or American species of powdery mildews that have appeared in Ukraine during the last 20 years. The vast majority of them have become permanent and common components of various plant communities here almost throughout the country. The only exception is E. kenjiana, the elm parasite, first recorded in Ukraine (Kyiv and Chernihiv only) in 2007 [Heluta et al., 2009b]. Initially, its development in these cities was epiphytotic, but in recent years it has been difficult to find the species. However, apparently the fungus penetrated from Ukraine into neighboring Romania, where it was recorded in two cities [Chinan, 2019]. We would like to emphasize that a number of species that migrated from East Asia became common in the countries west of Ukraine.

Erysiphe corylacearum, unlike the rest of the alien species listed above, is an East Asian-North American fungus because it has been recorded in both continents [Braun, 1982; Braun, Cook, 2012; Bunkina, 1991; Heluta, 1991; Heluta et al., 2019; Salmon, 1900]. Its recent findings in outside of the primary distribution range, viz. in 2013 in Turkey [Sezer et al., 2017], 2016 in Azerbaijan [Abasova et al., 2018] and Ukraine [Bulgakov, 2018], 2017 in Iran [Arzanlou et al., 2018] and southwestern Russia [Bulgakov, 2018], 2018 in Georgia [Meparishvili et al., 2019] may provide an evidence that the fungus has penetrated Ukraine probably from the eastward. Their records in the Ukrainian Carpathians indicate that the fungus is spreading further to westward. While this article was under preparation, a short report on the findings of $E$. corylacearum in Switzerland was published [Beenken et al., 2020]. In this country, this species was recorded in six localities in 2019. Therefore, given the ability of powdery mildews to quickly cover new territories, $E$. corylacearum will probably be expected next year also in other countries of Western Europe.

Common hazel is one of the important crops in some Mediterranean countries, most notably in Turkey, Italy, Spain and France. According to the observations of Turkish mycologists, in recent years the development of powdery mildew has caused noticeable damage to this species. The disease limits the production of hazelnuts, causing crop loss and poor product quality [Sezer et al., 2019]. Therefore, possible penetration of this fungus into the southern European countries, which are world leaders in the production of hazelnuts, will obviously lead to significant economic losses.

\section{CONCLUSIONS}

A dangerous alien fungus Erysiphe corylacearum, which causes powdery mildew of common hazel, an economically important crop, was recorded in Ukraine and Europe. The fungus was found in the Ukrainian Carpathians, a new and more western region compared to its previous findings. This indicates a rapid geographic expansion of E. corylacearum in Ukraine and noticeable invasive potential of this fungus. Without doubt, the fungus poses a threat to agriculture in the southern countries of Europe, especially for those that are leaders in the production of hazelnuts.

\section{ACKNOWLEDGMENTS}

The authors are grateful to the administration of Hutsulshchyna National Nature Park for supporting expeditionary research. The support offered by T.A. and A.R. Krupodorov during field research is much appreciated. We thank Dr. Vera Hayova for help with language editing and valuable comments on the manuscript. We also express our gratitude to the anonymous reviewer for careful reading of the manuscript and helpful suggestions. This work was supported by the budget program of the National Academy of Sciences of Ukraine "Support for development of the priority areas of scientific research" (CPCEL 6541230).

\section{REFERENCES}

Abasova L.V., Aghayeva D.N., Takamatsu S. (2018) Notes on powdery mildews of the genus Erysiphe from Azerbaijan. CREAM, 8(1): 30-53. DOI: $10.5943 / \mathrm{cream} / 8 / 1 / 3$

Arzanlou M., Torbati M., Golmohammadi H. (2018) Powdery mildew on hazelnut (Corylus avellana) caused by Erysiphe corylacearum in Iran. For. Pathol., 48(5): 1-4. DOI: 10.1111/efp.12450

Beenken L., Brodtbeck T., De Marchi R. (2020) First record of Erysiphe corylacearum on Corylus avellana in Switzerland and in central Europe. New Dis. Rep., 41,p. 11. doi.org/10.5197/j.2044-0588.2020.041.011

Braun U. (1982) Descriptions of new species and combinations in Microsphaera and Erysiphe (II). Mycotaxon, 15: 121-137. 
Braun U., Cook R.T.A. (2012) Taxonomic manual of the Erysiphales (Powdery mildews). CBS Biodiversity series No. 11. Netherlands, Utrecht: CBSKNAW Fungal Biodiversity Centre, $707 \mathrm{p}$.

Bulgakov T.S. (2018) Invasions of alien phytopathogenic fungi in the south of the European part of Russia in the 21st century: powdery mildew fungi on trees and shrubs. X Readings in the memory of O.A. Kataev. Dendrobiontic invertebrate animals and fungi and their role in forest ecosystems, vol. 2. Phytopathogenic fungi, issues of pathology and forest protection: proceedings of the international conference. St. Petersburg, October 22-25, 2018. Eds D.L. Musolin, A.V. Selikhovkin. SPb.: SPbGLTU, 11-12. [Булгаков Т.С. (2018) Инвазии чужеродных фитопатогенных грибов на юге европейской части России в XXI веке: мучнисторосяные грибы на деревьях и кустарниках. X Чтения памяти О.А. Катаева. Дендробионтные беспозвоночные животные и грибы и их роль в лесных экосистемах, вып. 2. Фитопатогенные грибы, вопросы патологии и защиты леса: материалы международной конференции. Санкт-Петербург, 22-25 октября 2018 г. Ред. Д.Л. Мусолин, А.В. Селиховкин. СПб .: СПбГЛТУ, 11-12.]

Bunkina I.A. (1991) Order Erysiphales. Nonvascular plants, fungi and bryophytes of the Soviet Far East. Fungi. Vol. 2. Ascomycetes. Erysiphales, Clavicipitales, Helotiales. Ed. Z.M. Azbukina. Leningrad: Nauka, 11-142. [Бункина И.А. (1991) Порядок Erysiphales. Низшие растения, грибы и мохообразные советского Дальнего Востока. Грибы. Т. 2. Аскомицеты. Эризифальные, клавиципитальные, гелоциальные. Ред. 3.М. Азбукина. Ленинград: Наука, 11-142]

Chinan V.-C. (2019) First report of Erysiphe kenjiana causing powdery mildew of elm in Romania. For. Pathol., 00:e12548: 1-3. doi.org/10.1111/efp.12548

Heluta V.P. (1991) Powdery mildew fungi (order Erysiphales) of the Kedrovaya Pad' Reserve. Mycology and Phytopathology, 25(5): 381-387. [Гелюта В.П. (1991) Мучнисторосяные грибы (порядок Erysiphales) заповедника «Кедровая падь». Микология и фитопатология, 25(5): 381387]

Heluta V.P. (2006) Overview of powdery mildew species (Erysiphales) introduced to Ukraine in recent decades. Synanthropization of vegetation of Ukraine (Pereyaslav-Khmelnytsky, April 27-28, 2006). Abstracts of scientific reports. Pereyaslav-
Khmelnytsky, 52-54. [Гелюта В.П. (2006) Огляд видів борошнисторосяних грибів (Erysiphales), інтродукованих в Україну протягом останніх десятиліть. Синантропізація рослинного покриву України (м. Переяслав-Хмельницький, 27-28 квітня 2006 р.). Тези наукових доповідей. Переяслав-Хмельницький, 52-54]

Heluta V.P., Dzyunenko O.O., Cook R.T.A., Isikov V.P. (2009a) New records of Erysiphe species on Catalpa bignoniodes in Ukraine. Ukr. Bot. J., 66(3): 346-353.

Heluta V.P., Hirylovich I.S. (2016) First records of an invasive fungus Podosphaera amelanchieris (Erysiphales) in Belarus and Ukraine. Ukr. Bot. J., 73(1): 78-83. DOI: 10.15407/ukrbotj73.01.078

Heluta V.P., Korytnyanska V.G. (2011) Golovinomyces greeneanus (U. Braun) Heluta, a new powdery mildew fungus (Erysiphales) in Ukraine. Ukr. Bot. J., 68(5): 773-779. [Гелюта В.П., Коритнянська В.Г. (2011) Golovinomyces greeneanus (U. Braun) Heluta (Erysiphales) - новий для України вид борошнисторосяних грибів. Укр. ботан. журн. 68 (5): 773-779]

Heluta V.P., Korytnianska V.G., Akata I. (2013) Distribution of Erysiphe platani (Erysiphales) in Ukraine. Acta Mycol., 48(1): 105-112.

Heluta V.P., Kovalchuk V.P., Chumak P.Ya. (2016a) First records of teleomorph of an invasive fungus Erysiphe macleayae (Erysiphales) in Ukraine. Ukr. Bot. J., 73(3): 268-272. DOI: 10.15407/ukrbotj73.03.268

Heluta V.P., Kravchuk O.O. (2015) First records of a new invasive fungus, Erysiphe macleayae (Erysiphales), in Ukraine. Ukr. Bot. J., 72 (1): 39-45. [Гелюта В. П., Кравчук О.О. (2015) Перші знахідки в Україні нового інвазійного гриба Erysiphe macleayae (Erysiphales). Укр. ботан. журн., 72(1): 39-45. doi.org/10.15407/ukrbotj72.01.039]

Heluta V.P., Makarenko N.V., Al-Maali G.A. (2019) First records of Erysiphe corylacearum (Erysiphales, Ascomycota) on Corylus avellana in Ukraine. Ukr. Bot. J., 76(3): 252-2 59. https://doi.org/10.15407/ ukrbotj76.03.252

Heluta V.P., Siahaan S.A.S., Takamatsu S. (2016b) Erysiphe symphoricarpi (Erysiphales), the first record in Ukraine. Ukr. Bot. J., 73(6): 604-611. DOI: 10.15407/ukrbotj73.06.604

Heluta V., Takamatsu S., Harada M., Voytyuk S. (2010) Molecular phylogeny and taxonomy of Eurasian Neoerysiphe species infecting Asteraceae and Geranium. Persoonia, 24: 81-92. DOI: 10.3767/003158510X501696 
Heluta V.P., Takamatsu S., Siahaan S.A.S. (2017) Erysiphe salmonii (Erysiphales, Ascomycota), another East Asian powdery mildew fungus introduced to Ukraine. Ukr. Bot. J., 74(3): 212-219. DOI: $10.15407 /$ ukrbotj74.03.212

Heluta V.P., Takamatsu S., Voytyuk S.O., Shiroya Y. (2009b) Erysiphe kenjiana (Erysiphales), a new invasive fungus in Europe. Mycol. Prog., 8(4): $367-$ 375. DOI: $10.1007 / \mathrm{s} 11557-009-0610-8$

Heluta V.P., Voytyuk S.O. (2004) Uncinula flexuosa Peck, a new invasive species of the powdery mildew fungi (Erysiphales) in Ukraine. Ukr Bot J., 61(5): 1725. [Гелюта В.П., Войтюк С.О. (2004) Uncinula flexuosa Peck - новий для України вид інвазійного борошнисторосяного гриба (Erysiphales). Укр. ботан. журн., 61(5): 17-25]

Heluta V.P., Voytyuk S.O., Chumak P.Ya. (2004) Microsphaera azaleae U. Braun, a new invasive species of the powdery mildew fungi (Erysiphales) in Ukraine. Ukr Bot J., 61 (2): 27-33. [Гелюта В.П., Войтюк С.О., Чумак П.Я. (2004) Microsphaera azaleae U. Braun - новий для України вид борошнисторосяного гриба (Erysiphales). Укр. ботан. журн., 61(2): 27-33]

Meparishvili G., Gur L., Frenkel O., Gorgiladze L., Meparishvili S., Muradashvili M., Koiava L., Dumbadze R., Reuveni M., Jabnidze R. (2019). First report of powdery mildew caused by Erysiphe corylacearum on hazelnuts in Georgia. Plant Dis., 103(11). doi.org/10.1094/PDIS-05-19-1053-PDN

Palagecha R.M., Chumak P.Ya. (2011) Ecological and morphological structure of the subpopulation of Microsphaera magnifica U. Braun (Erysiphales) and invasive ability of this fungus. Proceedings of the XIII Congress of the Ukrainian Botanical Society. Lviv: Prostir M, 313. [Палагеча P.M., Чумак П.Я. (2011) Еколого-морфологічна структура субпопуляції Microsphaera magnifica U. Braun (Erysiphales) та інвазійна спроможність цього гриба. Матеріали XIII з'їзду Українського ботанічного товариства. Львів: ТзОВ «Простір М», 313]

Salmon E.S. (1900) A monograph of the Erysiphaceae. Memoirs of the Torrey Botanical Club, 9: 1-292.

Seko Y., Bolay A., Kiss L., Heluta V., Grigaliunaite B., Takamatsu S. (2008) Molecular evidence in support of recent migration of a powdery mildew fungus on Syringa spp. into Europe from East Asia. Plant Pathol., 57(2): 243-250. DOI: 10.1111/j.13653059.2007.01775.x
Seko Y., Heluta V., Grigaliunaite B., Takamatsu S. (2011) Morphological and molecular characterization of two ITS groups of Erysiphe (Erysiphales) occurring on Syringa and Ligustrum (Oleaceae). Mycoscience, 52(3): 174-182. DOI: 10.1007/s10267-010-0088-x

Sezer A., Bilgen Y., Duyar Ö., Ciğdem Bulam Köse C., Gumuş E., Er T. (2019) Determination of chemical control possibilities against the powdery mildew caused by Erysiphe corylacearum in hazelnut production areas of Giresun province. Academic Journal of Agriculture, 8 (Special Issue): 71-78. doi.org/10.29278/azd.656526. [Sezer A., Bilgen Y., Duyar Ö., Ciğdem Bulam Köse C., Gumuş E., Er T. (2019) Erysiphe corylacearum'un neden olduğu külleme hastalığına karşı Giresun ili fındık üretim alanlarında kimyasal mücadele olanaklarının belirlenmesi. Akademik Ziraat Dergisi, 8 (Özel Say1): 71-78. doi.org/10.29278/azd.656526]

Sezer A., Dolar F.S., Lucas S.J., Köse Ç., Gümüş E. (2017) First report of the recently introduced, destructive powdery mildew Erysiphe corylacearum on hazelnut in Turkey. Phytoparasitica, 45(4): $577-$ 581. doi.org/10.1007/s12600-017-0610-1

\section{Ukraynada gəlmə Erysiphe corylacearum (Erysiphales, Ascomycota) göbələyinin yeni qeydiyyatı}

\section{Vasyl P. Heluta}

M.G. Xolodnı adına Botanika İnstitutu, Ukrayna Milli Elmlar Akademiyası, 2 Tereşçenkivska küç., Kiyev, 01004, Ukrayna

\section{Stella I. Fokşei}

Hutsulşçina Milli Tabiat Parkı, 84 Drujbaküç., Kosiv, 78600, Ivano-Frankivsk, Ukrayna

Məqalədə Ukraynada əvvəllər yalnız Kiyevdə iki lokalitetdə aşkar edilmiş gəlmə unlu şeh göbələyi Erysiphe corylacearum (Erysiphales, Ascomycota) barədə yeni məlumat verilir. 2019-cu il sentyabrın sonunda bu növ əlavə olaraq Hutsulşçina Milli Təbiət Parkında (İvano-Frankivsk regionu, Ukrayna Karpatı) altı yerdə tapılmışdır. Bu göbələk ilkin olaraq Şərqi Asiya-Şimali Amerika coğrafi aralığına malik olmuş, lakin son illər Türkiyə (2013), Azərbaycan (2016), Ukrayna (2016), İran (2017), Cənub-Şərqi Rusiya (2017), Gürcüstan (2018) və İsveçrədə (2019) də qeyd edilmişdir. Nəticə etibarilə, ehtimal edilir ki, bu növ Ukraynaya şərqdən daxil olmuşdur. Yeni lokalitetlərdən əksəriyyətində E. corylacearum adi findığı (Corylus avellana) əhəmiyyətli dərəcədə yoluxdurur, kisə və sporlara malik zəngin meyvə cismləri əmələ gətirir. 
Növün artıq Ukrayna Karpatında və İsveçrədə aşkar edilməsini, unlu şeh göbələklərinin yeni ərazilərə sürətlə yayılmasını nəzərə alaraq, ehtimal edilir ki, E. corylacearum Şərqi Avropanın bir çox ölkələrində tezliklə özünü biruzə verəcəkdir.

Açar sözlor: adventiv növ, Corylus, adi findıq, invasiya, unlu şeh, Ukrayna Karpatı

\section{Новые находки чужеземного \\ гриба Erysiphe corylacearum (Erysiphales, Ascomycota) на Украине}

\section{Василий П. Гелюта}

Институт ботаники им. Н.Г. Холодного НАН Украины, ул. Терещенковская, 2, Киев 01004, Украина

\section{Стелла И. Фокшей}

Национальный природный парк «Гуиульщиина», ул. Дружбы, 84, Косов 78600, Ивано-Франковская обл., Украина

Приводится информация о новых находках на Украине заносного мучнисторосяного гриба Erysiphe corylacearum (Erysiphales, Ascomycota), ранее зарегистрированного здесь только в Крыму и двух точках на территории Киева. Этот вид в конце сентября 2019 г. дополнительно обнаружен в Национальном природном парке «Гуцульщина» (Ивано-Франковская обл., Украинские Карпаты) в шести локалитетах. Гриб имеет первичный восточноазиатско-североамериканский ареал, однако в последние годы стал встречаться в Турции (2013), Азербайджане (2016), Украине (2016), Иране (2017), на юго-западе России (2017), в Грузии (2018) и только в прошлом году - в Швейцарии (2019). Поэтому сделан вывод, что он попал на Украину из восточного направления. В большинстве новых локалитетов E. corylacearum значительно поражал лещину (Corylus avellana) и обильно формировал плодовые тела с сумками и спорами. Учитывая то, что этот вид уже зарегистрирован в Украинских Карпатах и Швейцарии, а также способность мучнисторосяных грибов быстро охватывать новые территории, предполагается его распространение в ближайшее время в разных странах Западной Европы в ближайшем будущем.

Ключевые слова: адвентивный вид, Corylus, лещиина, инвазия, мучнисторосяные грибы, Украинские Kapnambl 